\title{
Novel Findings on Gender Differences in Self- \\ Disclosure: The Sharing of Personal Information in Japanese Students' Close Friendships
}

Peter Fankhauser

\begin{abstract}
Contrary to common findings on self-disclosure and gender, male students at a Japanese university that were questioned for this study reported significantly higher disclosure to close friends than their female colleagues - overall as well as for various individual topics $(N=479)$. Two different measures of self-disclosure were used, both yielding similar results. The gender differences were especially pronounced in cross-gender friendships. In accordance with previous literature, subjective feeling of closeness and respondents' trust in the stability of the friendship were found to be positively associated with self-disclosure. While both closeness and trust in relationship stability were greater in same-gender friendships, no gender differences were found in this regard. The conclusion discusses the possibility of these findings being connected to shifting images of masculinity and femininity among Japanese youth, as well as changing interaction patterns between genders. ${ }^{1}$
\end{abstract}

Keywords: self-disclosure, gender differences, friendship, Japan

Fankhauser, Peter. 2018. "Novel Findings on Gender Differences in Self-Disclosure: The Sharing of Personal Information in Japanese Students' Close Friendships." Vienna Journal of East Asian Studies, 10, pp. 1-30.

https://doi.org/10.2478/vjeas-2018-0001

\footnotetext{
${ }^{1}$ This paper is an abbreviated version of parts of the author's Master's thesis (Fankhauser 2017).
} 


\section{Introduction}

Self-disclosure - the sharing of personal information about one's self-has received great attention in psychology and social psychology for decades; and since the early days of self-disclosure research, gender differences have held a prominent position. Considering various factors such as type of relationship, gender of disclosure target, and conversation topic, it is usually found that women display greater disclosureespecially in close relationships such as friendships (Dindia and Allen 1992; Horesh-Reinman 2011). In Japan, these findings have been replicated numerous times (Enomoto 1997; Shimakura and Miyamoto 2013). Only in rare cases and in regard to specific topics men's self-disclosure has been found to be higher. The present paper presents different and surprising findings: among a sample of 479 students at a Japanese university, male students reported significantly higher disclosure to close friends than female students did for various topics and across two different measures of self-disclosure. Initially, this paper will provide a short introduction to the topic, followed by a literature review focusing on gender differences in self-disclosure. After a brief look at the underlying method of this quantitative study, I will present the results of my statistical analysis, consisting mainly of group comparison and correlation analysis. Besides self-disclosure and gender, correlation with the subjective feeling of closeness and the respondents' trust in the stability of the friendship are also considered.

Self-disclosure, or jiko kaiji 自己開示 in Japanese, refers to the sharing of personal experiences, thoughts, or emotions with others through the speaker's frame of reference (see Andō 1990; Derlega et al. 1993; Jourard 1958). In the Encyclopedia of Social Psychology, Amy Brunell (2007: 810-811) states that self-disclosure "is considered a key aspect of developing closeness and intimacy with others, including friends, romantic partners, and family members" and draws attention to the widely held belief among researchers "that experiencing intimacy through self-disclosure may be the most important factor that determines the health of a relationship." Selfdisclosure can refer to anything, from telling others about one's favourite sports team to sharing childhood memories or revealing one's innermost dreams.

Self-disclosure serves several functions in relationships, most important of which is relationship development through the creation of intimacy. Others include social validation, the attainment of social control, or the therapeutic effect of selfdisclosure through emotional catharsis (Derlega et al. 1993; Omarzu and Harvey 2012: 496). Moreover, self-disclosure can have a positive effect on psychological health, may help attain social support, boost self-esteem, and improve coping with stress (Derlega et al. 1993: 110-111). Andō (1986) identifies six functions of selfdisclosure, divided into two categories: expression, self-clarification, and social validation are primarily important for intra-personal processes, while reward, social control, and regulation of intimacy are more relevant to interpersonal processes. 
Self-disclosure is often described using the features broad and deep. Breadth refers to the range of different topics, whereas depth to the degree of intimacy of the information shared (Brunell 2007: 811). Self-disclosure is reciprocal, thus increased sharing by one friend or relationship partner will usually positively affect the other party's level of self-disclosure and vice versa. This aspect is central to the theory of social penetration (Altman and Taylor 1973). Omarzu and Harvey (2012: 469) underline that self-disclosure is a discretionary behaviour, so individuals are to a large degree capable of choosing how much and to whom they disclose. Thus, it can also be goal-oriented.

This paper takes up the rather recent approach of understanding self-disclosure not only as a psychological trait, but as a behavioural pattern strongly embedded in a social context. It is understood here as involving choices of interaction and the way these are influenced by one's socialisation and the surrounding society. What and how much information individuals share about themselves is not just an expression of their personality; it is also a matter of expectations directed towards themselves, as it is dependent on the roles which people assume in a specific social environment-including gender roles. Many factors can affect the decisions of what and how to disclose: the way they have been socialised, the groups they have been socialised into, the values learned as well as the expectations directed towards them, and pending sanctions they might expect from their surrounding (cf. Derlega et al. 1993: 44-57).

This is connected to the influence of cultural aspects which also play a role in the research on self-disclosure. Barnlund $(1975 ; 1989)$ found indication that selfdisclosure was higher in individualistic cultures compared to collectivistic ones, including Japan. This is supported by other researchers who find Chinese or Japanese to disclose less than U.S.-Americans (Chen 1995; Ting-Toomey 1991). The typical and somewhat reductionist explanation for lower self-disclosure in Japan puts an emphasis on (a presupposed) harmony within the culture; usually, it is concluded that a more cautious or 'sensitive' disclosure arises from this (TingToomey 1991; Kito 2005).

Nevertheless, self-disclosure is generally accepted in psychological literature as one of the most central aspects in human relationships regardless of culture, especially in intimate relationships such as friendships (Altman and Taylor 1973; Bauminger et al. 2008; Collins and Miller 1994; La Gaipa 1977; Walker and Wright 1976). Although the concepts of 'friend' or 'best friend' are not necessarily the same across cultures (Maeda and Ritchie 2003), the importance of self-disclosure for any type of friendship seems universal. In Japan, a high value is assigned to self-disclosure in friendships as well (Ochiai and Satō 1996; for same-gender friendships, see Wada 1993).

Gender is one aspect which has been found to strongly influence disclosure both in Japan and elsewhere, with the overall result that women's disclosure tends to be 
greater than men's (Derlega et al. 1993; Dindia and Allen 1992; Enomoto 1987; Jourard 1971b). But interaction patterns and the way people define various types of relationships are not static; they change all the time, just as gender roles and social context do. Thus updating and re-examining earlier findings always carries the potential of revealing unexpected results — as is the case in the present study.

\section{Literature Review}

In this overview of international and Japanese literature on self-disclosure, research concerned with the clinical aspects of self-disclosure has been omitted because it is not relevant to the present study. Furthermore, the review focuses on survey-based research designs as opposed to experimental studies, since the latter are prevalent in research on first-time encounters instead of close relationships.

\section{Early and 'Western' Research on Self-Disclosure}

The term self-disclosure was coined in the late 1950s by the Canadian psychologist Sidney M. Jourard. Together with sociologist Paul Lasakow, they developed the first self-reported measure of self-disclosure, the Jourard Self-Disclosure Questionnaire (JSDQ) (Jourard and Lasakow 1958). Already in his early studies he found that female students displayed greater disclosure than male students (Jourard 1971b: 11).

Jourard conceptualised self-disclosure as reciprocal (also called dyadic effect of self-disclosure). As already mentioned, this reciprocity plays a major role in the theory of social penetration by Irwin Altman and Dalmas A. Taylor, who first formulated the idea in the early 1970s (Altman and Taylor 1973). In their view, the ever greater 'making known' of the self to the other will help to peel off layer after layer of guards and restrictions and lead to more intimate and more satisfying relationships. In four stages, relationships move from initial encounters, where the primary objective of both conversation partners is conflict avoidance, to a form of stable exchange, where openness is a constant factor and both parties have become proficient in interpreting and predicting each other's behaviour (Taylor and Altman 1987: 259).

Walker and Wright (1976) have shown that greater self-disclosure-especially intimate disclosure which involves very personal experiences or one's innermost feelings - has a positive effect on friendship development. Working with a Canadian sample, La Gaipa (1977) identified self-disclosure as one of eight factors important in friendships together with, among others, helping behaviour and similarity. On the other hand, Argyle and Henderson (1985) found evidence that a lack of disclosure (especially of confidences) can be detrimental to a friendship. Overall, it can be said that the first generation of self-disclosure research was strongly focused on the 
Northern American geographical sphere and still understood self-disclosure primarily as a tool to create intimacy - while a lack of disclosure was seen as a pathological sign in a relationship.

The assumption in social penetration theory that the mutual exchange would "proceed in a gradual and orderly fashion" (Taylor and Altman 1987: 259) and mutual liking and trust would also increase, was later somewhat put into perspective. In 1993, referring to social penetration theory as well as the writings of Sidney Jourard, Derlega et al. criticised that a "casual reading of early work on selfdisclosure [...] might suggest that self-disclosure is synonymous with a close relationship" (1993: 2). They acknowledged that self-disclosure can be a powerful tool in creating an intimate relationship, but they also pointed out that decisions to disclose are regulators of privacy and can create vulnerability as well as conflict (ibid.: 86-87). They also re-examined the question of gender. Generally in the 1990s, an increased interest in gender differences can be observed in self-disclosure research (Daubman and Sigall 1997; Dolgin and Minowa 1997; Shaffer et al. 1996).

\section{Gender Differences in Self-Disclosure}

Jourard's early findings that women disclose more - in frequency, breadth, and depth-was reproduced in numerous studies using samples from North America. Caldwell and Peplau (1982), for example, noted lower self-disclosure in samegender friendships among male than female students when asked about the topics of feelings and personal problems. However, this discrepancy did not align with assessments of intimacy of these friendships, leading the authors to the conclusion that

\footnotetext{
[m]en and women may be equally likely to define friends as intimate; however, men and women may have different standards for assessing the intimacy of friendship. Because the male gender role restricts men's self-disclosure to other men, small degrees of personal revelation to a male friend may be taken as a sign of considerable intimacy [...] (ibid.: 731).
}

Jourard (1971a: 35 ) also tried to explain this difference through gender roles, believing that the male role required a man to "hide much of his real self $[\ldots]$ from himself and from others" in order "to appear tough, objective, striving, unsentimental, and emotionally unexpressive." Most 'western' self-disclosure research of the 1970s and 1980s follows this line of reasoning in regard to gender differences (e.g., Taylor and Hinds 1985; Thase and Page 1977). However, many of these studies already hinted at the necessity of sufficient differentiation between disclosure topics. Derlega et al. (1981), while controlling for gender of discloser and disclosure target as well as degree of friendship, differentiated between topics stereotypically understood as 'feminine,' 'masculine,' and 'neutral.' In the case of 'feminine' topics, women's disclosure was indeed higher. For the other two categories, however, no differences 
were found in two of the three experiments they conducted. Thus men's disclosure was not found to be higher for the typically 'masculine' topics.

A meta-analysis on gender differences in self-disclosure published in 1992 included 205 studies between 1958 and 1989 (only white North American subjects). This study indeed found a small effect of gender on self-disclosure across various types of relationships $(d=.18)$, with greater self-disclosure on the part of women. When only considering friendships, this effect was noticeably larger $(d=.28)$ (Dindia and Allen 1992).

Derlega et al. (1993) reasoned that this dissimilarity might be related to the different subcultures in which men and women find themselves. They argued that there are two main aspects to the understanding of gender and self-disclosure: a general cultural expectation of openness and sharing personal information, and the notion of subcultures in which different norms exist which shape behaviour and interactions. Due to their socialisation in different subcultures, men and women "may not only reveal different preferences for and patterns of self-disclosure but also have different interpretations of the meaning and purpose of self-disclosure" (ibid.: 63).

In the years following the work of Dindia and Allen, support for this finding on gender remained mainstream (Horesh-Reinman 2011). All in all, it can be claimed that western research on self-disclosure supports the idea that women display greater self-disclosure although this is limited to certain topics. Introductory literature on social psychology and interpersonal communication even includes the greater disclosure of women as a preliminary aspect of self-disclosure (Brunell 2007).

\section{Self-Disclosure Research in Japan: Focus on Students' Friendships and Gender}

Japan-based research on self-disclosure has been shaped foremost by Enomoto Hiroaki 榎本 博明, who started conducting work on this topic in the early 1980s. In line with Jourard, Enomoto's self-disclosure measure (the Enomoto Self-Disclosure Questionnaire, or ESDQ) asks for disclosure towards best same-gender and different-gender friend, mother, and father. The questionnaire he developed can be divided into six different aspects of the self: psychological self (including one's emotions, aspirations, and self-consciousness/confidence); physical self (including one's physical appearance, health, and sexuality); social self (including one's relations to other people as well as one's opinion about public and social matters); material self (including one's money spending and interest in material goods); relational self (including one's familial matters); and existential self (including one's feeling of purpose of life or alienation) (Enomoto 1987: 92; 1997: 15).

In an influential 1997 monograph, Enomoto devotes one whole chapter to the question whether women's self-disclosure is higher (Enomoto 1997: 84-90). His review of western literature on the topic concludes that there is ample evidence to 
support the general notion that women display greater self-disclosure than men. He also refers to his earlier research on Japanese college students: in all areas of selfdisclosure defined by Enomoto, the female students disclosed more overall than their male colleagues, although this difference was only significant when it came to the area of family-related information, i.e., the relational self (Enomoto 1987). When separated by disclosure target, he found that disclosure among both genders was strongest to a same-gender friend and lowest to father. Women, however, disclosed more towards all four targets, and significantly so towards father and mother.

In friendships, significant differences between the genders were only shown when separating by disclosure topic and disclosure target. In the case of differentgender friends, only the area of family matters was significant, and for all other thematic areas no significant differences could be observed. Disclosure to one's closest friend of the same gender, however, revealed a different picture: female students shared significantly more than male students in the areas of emotions/emotional experiences, familial matters, and things having to do with their physical appearance (material self). Yet they disclosed significantly less than male students to their closest friends of the same gender in regard to matters of sexuality.

Disclosure was highest towards same-gender friends as opposed to differentgender friends, mother, and father in all cases. Another of Enomoto's findings is that, for male students, their same-gender friend was the only primary self-disclosure target, while female students also disclosed quite strongly towards their mothers. Male students even disclosed more readily towards different-gender friends than towards their mothers (Enomoto 1987: 94-95; 1997: 27-37).

Among friends, topics such as hobbies were readily disclosed, while topics of less open disclosure were sexuality, personal relationships with other people, and family matters (Enomoto 1997: 30-32). Enomoto concludes that women show a tendency towards higher disclosure, as western literature would suggest - however, factors such as type of relationship and topic of conversation make the matter more complex and call for more research (ibid.: 99).

More recent findings support the assumption that women's self-disclosure in Japan is significantly higher than that of men, such as the work of Shimakura and Miyamoto (2013) who also look at disclosure depth. They used a scale developed by Niwa and Maruno (2010) to measure disclosure depth. The first level only covers hobbies and other superficial (mainly descriptive) information about the self that can still help in creating topics of conversation and promote relationship development. The second level of disclosure-depth covers the broad range of difficult experiences and how they were overcome. The third level includes foibles and weaknesses which are not defining or unchangeable and are generally not expected to induce a final negative judgment by the other party. Finally, the fourth and deepest level of selfdisclosure identified by Niwa and Maruno (2010) concerns negative or inferior character traits and abilities (or lack thereof). These last two deeper levels of disclo- 
sure are more readily shared with closer friends as opposed to other types of friends (Takeda et al. 2012). In the study by Shimakura and Miyamoto (2013), female students reported greater self-disclosure than their male colleagues for all four levels.

Takeuchi (2010: 20-22) found another interesting gender effect. She analysed self-disclosure to three different types of friends: close friends, 'normal friends,' and acquaintance-like friends. There was no significant gender effect in regard to selfdisclosure towards acquaintance-like friends but, for the other two types, women disclosed more than men in same-gender friendships. When looking at the case of close different-gender friendships, however, males' disclosure was significantly greater than that of females. No significant differences were observed for the other two types of different-gender friendships. Thus, overall, male students' selfdisclosure towards their female friends was greater than vice versa.

It can be said that Japanese research of self-disclosure largely supports the notion that female students' disclosure is higher than that of their male colleagues, particularly in the case of same-gender friendships and concerning some specific topics. However, there are also topics and friendship constellations where evidence exists for men's disclosure to be similar or even greater than that of women.

In research on self-disclosure the use of modern communication technology has become a primary focus of attention, both in Japan and elsewhere (Ledbetter et al. 2011; Rains et al. 2014; Rains and Brunner 2018; Ue and Horiuchi 2012). In a study conducted in Taiwan, female bloggers' disclosure was found to be higher than that by male bloggers in everyday life, while these differences disappeared in front of online audiences (Tang and Wang 2012). A similar study argued that the internet is becoming a place of self-disclosure for Japanese students, where differences based on gender do not matter as much as in face-to-face disclosure situations because it is easier for men to disclose more online. With the exception of societal topics, this study reported only small or hardly any differences in men's and women's selfdisclosure in regard to such topics as family matters, everyday life, and relationships with people of the opposite gender (Noguchi 2011: 124).

Based on the results presented above, the present study wants to contribute to a more reliable view of the interrelation of self-disclosure and gender in close friendships with a focus on Japan. One strategy used to improve on the reliability of extant research was the application of two separate measures of self-disclosure. In carrying out this study, I also pay heed to the ever changing nature of social codes of communication as well as gender relations. Furthermore, the sample used here is greater than in almost all of the studies that have so far been conducted in Japan and elsewhere. 


\section{Method}

The data used here were collected at a public university in Tōkyō prefecture from May to June 2015. Cooperating teaching personnel were asked to devote lecturetime to the conduction of the survey. Students were informed that the survey was about friendships and part of a Master's thesis in Japanese studies. 617 questionnaires were distributed of which 538 were returned, with the number of respondents per class ranging from 12 to 157 ( 15 classes in total). Out of these, 479 were sufficiently completed for analysis, amounting to a response rate of 77.6 per cent.

\section{Research Design}

The questionnaire asked respondents to report on the relationships to their closest female friend and their closest male friend. A third section was included to account for a third friend who did not identify with either gender, but few respondents made use of this section, which is the reason it is not separately considered here.

As a unique characteristic of the present study, two measures of self-disclosure were used. One, which was taken from a study by Schug et al. (2010), is a short fiveitem measure that draws on conventional measures of self-disclosure and was created in a process involving both US and Japanese focus groups (henceforth, measure A). The second measure used in this study (henceforth, measure B) is the SelfDisclosure Index by Miller et al. (1983), which consists of ten items and has been applied to various research designs (e.g., Fisher and Choi 2013; Kito 2005; Sprecher and Hendrick 2004).

Due to the mutual influence (reciprocity) between intimacy and degree of selfdisclosure noted in the literature, a measure of subjective closeness was also included into the research design, as was a measure of trust in the stability of the friendship. As explained above, self-disclosure, especially at deeper levels, can make the discloser vulnerable. Taking this risk is likely connected to how safe one feels in a certain relationship and how stable one considers it to be, which is why association effects between these variables and self-disclosure are investigated. All of these associations will be controlled for possible gender differences.

\section{Measures}

Measure A asked about the likeliness of respondents sharing with their specific close friend: "a) their biggest secret, b) their most embarrassing experience, c) their greatest failure, d) their greatest worry, and e) the worst thing that ever happened to them" (Schug et al. 2010: 1472). Answer options ranged from "not very likely" to "extremely likely" on a five-point scale. 
Measure B asked how often respondents shared certain information with their respective close friend. The topics were: a) one's personal habits; b) things done in the past for which one feels guilty; c) things one would not do in public; d) one's deepest feelings; e) what one likes or dislikes about oneself; f) what is important to one's life; g) what is important for one's identity (i.e., being oneself); h) the things one most fears; i) things one holds pride in; and j) one's close relationships with other people. Responses ranged from "not at all" to "fairly often" on a five-point scale. Thus, while measure A asks for likelihood of target-specific disclosure, measure B asks for respondents' actual disclosure situations.

Both measures of self-disclosure used in this study refer to fairly intimate topics of conversation. Rather than breadth of self-disclosure, there is a focus on 'deep' disclosure topics. This is especially the case for measure A with its focus on rather negative content. The topics would most likely fall into the fourth and deepest level of self-disclosure according to Niwa and Maruno (2010). Measure B is broader and less 'negative' in its choice of topics - although most of the ten items are very personal.

As suggested by the creators of the scales, non-weighted indices were created and then normalised to result in quasi-continuous variables from 1 to 5 . Both measures proved to be highly reliable for both disclosure to same-gender friend (A: $\alpha=.86, n=474 ; \mathrm{B}: \alpha=.87, n=468$ ) and different-gender friend (A: $\alpha=.85, n=$ 411; B: $\alpha=.86, n=412$ ).

Similarly to Schug et al. (2010), the present study made use of the Subjective Closeness Index by Berscheid et al. (1989), with minor adaptions. The measure used here consists of two items that ask the respondents to indicate the degree of closeness with their friend a) in comparison with all of their other friendships and b) in comparison with what they know about other people's friendships. The ten-point unipolar scales of the original measure were replaced with $97 \mathrm{~mm}$ visual analogue scales (a straight line with labelled endpoints, on which respondents made a mark). Only the combined measure (ranging from 0 to 97 ) will be discussed.

The item of Trust in friendship stability, also using a visual analogue scale as described above, asks the respondents how likely they believe their friendships will still be the same ten years later.

Additionally, respondents were asked to name the one person with whom they could talk about anything (or the person who comes closest to this ideal) to determine their preferred target of disclosure. This item is called the Primary target of self-disclosure.

\section{Sample}

The sample consists of 479 students from a Japanese public university in Tōkyō prefecture 東京都. The respondents were, on average, 19.45 years old $(S D=1.861)$ 
at the time of the survey. Male respondents were slightly older (19.66 years; $S D=$ $2.184)$ than their female colleagues $(19.15$ years; $S D=1.185)$ and thus also further advanced in their university education. Table 1 shows the respondents' distribution by gender and year of study at the university.

Table 1: Respondents by gender and year of study at the university

\begin{tabular}{|c|c|c|c|c|c|c|}
\hline & \multicolumn{4}{|c|}{ Year at university } & \multirow[b]{2}{*}{ Total } \\
\hline & & $1^{\text {st }}$ year & $2^{\text {nd }}$ year & $3^{\text {rd }}$ year & $\begin{array}{c}4^{\text {th }} \text { year } \\
\text { and above }\end{array}$ & \\
\hline \multirow[t]{4}{*}{ Gender } & Male & 98 & 108 & 60 & 18 & 284 \\
\hline & Female & 92 & 57 & 33 & 11 & 193 \\
\hline & $\mathrm{FtX}^{2}$ & 1 & 1 & 0 & 0 & 2 \\
\hline & Total & 191 & 166 & 93 & 29 & 479 \\
\hline
\end{tabular}

Source: Fankhauser 2017: 44.

The few graduate students who took part in the survey were combined with senior undergraduates into the fourth category. As can be realised, the proportion of men is considerably higher in this sample (male: 59.7 per cent; female: 40.3 per cent) and representativity in respect to gender cannot be assumed. Only nine respondents were non-Japanese citizens.

\section{Analysis}

In this section, individual items from both measures of self-disclosure as well as the combined indices are reported and compared by gender. For reasons of comprehensibility, these results are separated by measure and disclosure target. Means for subjective closeness and trust in the durability of the friendship are also reported. Lastly, correlation results are presented. All variables are tested for gender differences using group comparison. ${ }^{3}$

\footnotetext{
2 There were only two respondents who defined themselves as anything other than 'male' or 'female,' namely 'FtX.' These cases, given their small number, are not considered separately here. ${ }^{3}$ As for the interpretation of effect sizes, rules proposed by Cohen (1988) and Evans (1996) have been applied. For non-parametric group comparisons: $r=.10-.29$ is considered "small"; $r=.30-.49$ is considered "medium"; and $\mathrm{r} \geq .5$ is considered "large." Associations produced by correlation analysis is interpreted as following: .00-.19 = "very weak"; $.20-.39=$ "weak"; $.40-.59=$ "moderate"; $.60-.79=$ "strong"; $.80-1.0=$ "very strong." Statistical Analysis was conducted using IBM SPSS Statistics 19.
} 


\section{Self-Disclosure and Gender Differences by Type of Friendship: Measure A}

Table 2 depicts mean responses to self-disclosure measure A by respondent's gender and in the case of same-gender friendships. The five topics of self-disclosure are those surveyed also by Schug et al. (2010); however, no comparable overview was published in their study which included more than twenty-nine female respondents.

Table 2: Self-disclosure to same-gender friend by topic: Means (Measure A)

\begin{tabular}{|l|c|c|c|c|c|c|}
\hline \multirow{2}{*}{\multicolumn{1}{|c|}{ Items }} & \multicolumn{3}{c|}{ Male } & \multicolumn{3}{c|}{ Female } \\
\cline { 2 - 7 } & $\mathrm{N}$ & Mean & SD & N & Mean & SD \\
\hline Your biggest secret & 282 & 3.04 & 1.40 & 192 & 2.61 & 1.47 \\
\hline Your most embarrassing experience & 282 & 3.52 & 1.27 & 192 & 3.19 & 1.41 \\
\hline Your greatest failure & 282 & 3.65 & 1.21 & 192 & 3.37 & 1.37 \\
\hline Your greatest worry & 282 & 3.32 & 1.33 & 192 & 3.43 & 1.40 \\
\hline The worst thing that ever happened to you & 282 & 3.67 & 1.18 & 192 & 3.51 & 1.29 \\
\hline
\end{tabular}

Respondents were asked: "Do you speak to this friend about the following topics? Please assess how likely that is?" Answers were given on a five-point scale with the labels "Not likely" (1) and "Extremely likely" (5) attached on either side.

Source: Fankhauser 2017: 45.

Both men and women would most readily talk about the worst thing that ever happened to them. Their biggest secret was the topic least likely to be disclosed. Statistically significant differences based on Mann-Whitney $U$-tests can be seen in Figure 1 (marked with asterisks).

Figure 1: Self-disclosure to same-gender friend by topic: Gender differences (Measure A)

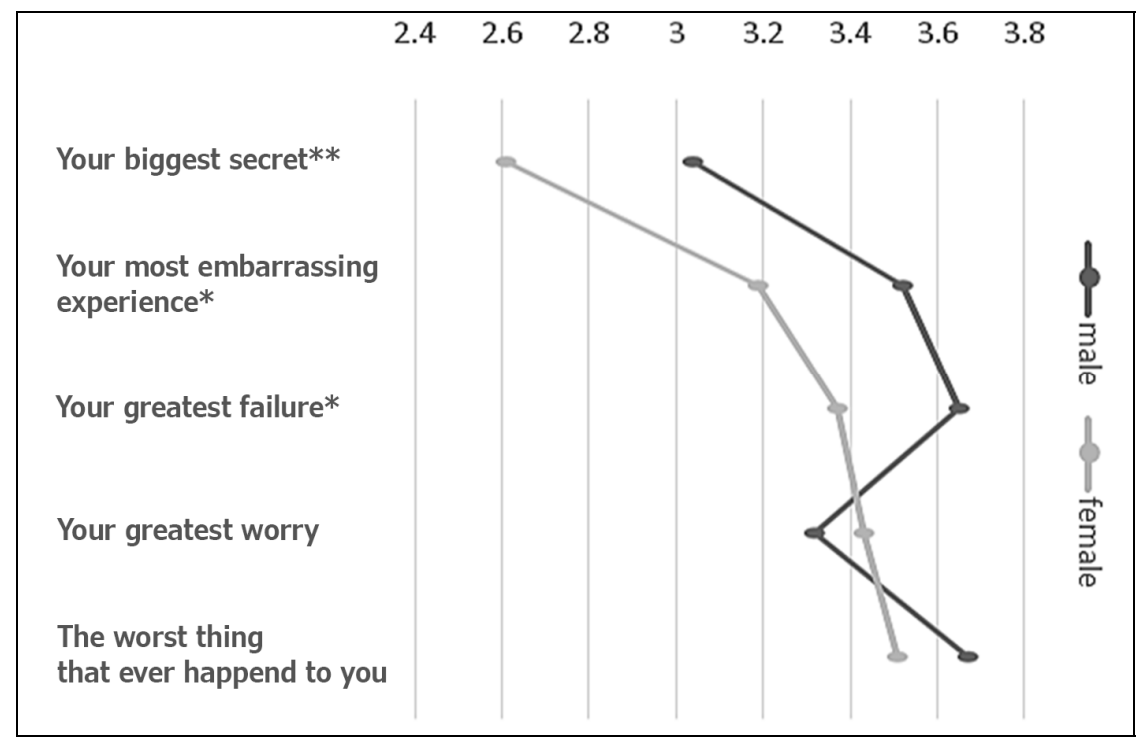

Note: $*: \mathrm{p}<.05, * *: \mathrm{p}<.01, * * *: \mathrm{p}<.001 ;$ Source: Fankhauser 2017: 55 
$U$-tests yield significant gender differences in self-disclosure for three out of these five topics. Female respondents deemed it significantly less likely than men to disclose to their closest same-gender friend when it came to their biggest secret $(u=$ 22568.0, $p=.002, r=.145)$, their most embarrassing experience $(u=23711.0, p$ $=.018, r=.109)$, and their greatest failure $(u=24200.5, p=.042, r=.093)$. No significant differences were found for the other two items. Judging from the small effect sizes reported here, the influence of gender appears to be limited.

Table 3: Self-disclosure to different-gender friend by topic: Means (Measure A)

\begin{tabular}{|l|c|c|c|c|c|c|}
\hline \multirow{2}{*}{\multicolumn{1}{|c|}{ Items }} & \multicolumn{3}{c|}{ Male } & \multicolumn{3}{c|}{ Female } \\
\cline { 2 - 7 } & $\mathrm{N}$ & Mean & $\mathrm{SD}$ & $\mathrm{N}$ & Mean & $\mathrm{SD}$ \\
\hline Your biggest secret & 244 & 2.52 & 1.38 & 169 & 1.94 & 1.12 \\
\hline Your most embarrassing Experience & 243 & 2.89 & 1.34 & 169 & 2.46 & 1.36 \\
\hline Your greatest failure & 244 & 3.11 & 1.31 & 169 & 2.65 & 1.40 \\
\hline Your greatest worry & 244 & 3.02 & 1.32 & 169 & 2.63 & 1.40 \\
\hline The worst thing that ever happened to you & 243 & 3.23 & 1.26 & 169 & 2.77 & 1.36 \\
\hline
\end{tabular}

See Table 2. Source: Fankhauser 2017: 46.

In Table 3, mean values of self-disclosure in different-gender friendships are reported. Here too, one's worst experience is the topic most readily shared, whereas one's biggest secret is least likely to be disclosed by male and female students alike.

Figure 2: Self-disclosure to different-gender friend by topic: Gender differences (Measure A)

Your biggest secret***
$\begin{aligned} & \text { Your most embarrassing } \\ & \text { experience** }\end{aligned}$
Your greatest failure**
Your greatest worry**
The worst thing that
ever happened to you $* *$

Note: $*: p<.05,{ }^{* *}: p<.01,{ }^{* * *}: p<.001$. Source: Fankhauser 2017: 56. 
However, as shown in Figure 2, significant gender differences can be found for all five topics. Female students find it significantly less likely than male students to disclose to their different-gender friend: their biggest secret $(u=15820.0, p<.001, r$ $=.206)$; their most embarrassing experience $(u=16788.0, p=.001, r=.159)$; their greatest failure $(u=16635.5, p=.001, r=.168)$; their greatest worry $(u=17351.0, p$ $=.005, r=.138)$; and the worst thing that ever happened to them $(u=16500.0, p$ $=.001, r=.171)$. Effect sizes are slightly and non-significantly greater for differentgender friendships.

\section{Self-Disclosure and Gender Differences by Type of Friendship: Measure B}

In the case of measure B, viz. the ten-item Self-Disclosure Index by Miller et al. (1983), significant effects of gender and type of relationship can be observed as well. In Table 4, means and standard deviation are reported for same-gender friendships.

Table 4: Self-disclosure to same-gender friend by topic: Means (Measure B)

\begin{tabular}{|l|c|c|c|c|c|c|}
\hline \multirow{2}{*}{\multicolumn{1}{|c|}{ Items }} & \multicolumn{3}{c|}{ Male } & \multicolumn{3}{c|}{ Female } \\
\cline { 2 - 7 } & $\mathrm{N}$ & Mean & SD & N & Mean & SD \\
\hline Your personal habits & 282 & 4.03 & 0.97 & 192 & 4.08 & 0.92 \\
\hline $\begin{array}{l}\text { Things you have done in the past } \\
\text { which you feel guilty about }\end{array}$ & 282 & 3.52 & 1.25 & 191 & 3.12 & 1.16 \\
\hline Things you wouldn't do in public & 282 & 3.57 & 1.28 & 191 & 3.21 & 1.15 \\
\hline Your deepest feelings & 282 & 3.49 & 1.27 & 192 & 3.63 & 1.12 \\
\hline What you like and dislike about yourself & 282 & 3.35 & 1.28 & 191 & 3.37 & 1.17 \\
\hline What is important to you and your life & 282 & 3.65 & 1.13 & 191 & 3.82 & 1.00 \\
\hline What is important for you to be you & 282 & 3.21 & 1.30 & 192 & 3.03 & 1.29 \\
\hline The things you most fear & 282 & 3.22 & 1.31 & 192 & 2.91 & 1.29 \\
\hline Things you hold pride in & 282 & 3.46 & 1.23 & 191 & 3.02 & 1.14 \\
\hline Your close relationships with other people & 282 & 3.65 & 1.14 & 191 & 3.37 & 1.12 \\
\hline
\end{tabular}

Respondents were asked: 'To what degree do you talk to this friend about the following topics? Please circle the most appropriate answer.' Possible answers were given on a five-point scale, ranging from 'Not at all' (1) to 'Fairly often' (5).

Source: Fankhauser 2017: 47.

Among the topics proposed by Miller et al. (1983), both male and female students' average scores are highest for the item "my personal habits." High levels of disclosure relative to the other topics are also reported for the item "What is important to you and your life." For male students, self-disclosure about their close relationships with other people is equally high. For the female respondents, "your deepest feelings" is found to be the third most-frequently disclosed topic, whereas this item ranks sixth in the case of their male colleagues.

The topics least frequently shared with same-gender close friends are "The things you most fear" (women) and "What is important for you to be you" (men). Female 
students also report low scores of self-disclosure for "things you hold pride in" and things from the past which they feel guilty about.

Figure 3: Self-disclosure to same-gender friend by topic: Gender differences (Measure B)

Things you have done in the past
which you feel guilty about***
Your personal habits
Things you wouldn't do in public**
Your deepest feelings
What you like and dislike
about your self
What's important to you
and your life
What's important for you
to be you
The thingsyou most fear*
Things you hold pride in***
Your close relationships
with other people**

Note: $*: p<.05,{ }^{* *}: p<.01,{ }^{* * *}: p<.001$. Source: Fankhauser 2017: 57

Figure 3 shows average responses and statistically significant gender differences using measure B. In order to provide a better overview, results of the Mann-Whitney $U$-tests are reported in Table 5. Although the $U$-test uses ranks, means are reported instead of the median, as the former are more suited to give a view of the differences.

There are gender differences in self-disclosure to same-gender friend for half of the ten topics included in the index. These topics are guilt-inducing experiences of the respondents $(r=.173)$, things they would not do in public $(r=.156)$, things they most fear $(r=.118)$, things they hold pride in $(r=.191)$, and their close relationships with other people $(r=.126)$. All of the observed effects indicate lower selfdisclosure on the part of female students. For the remaining five of the included topics, no gender differences were observed. 
Table 5: Gender differences in self-disclosure to same-gender friends: Group comparison (Measure B)

\begin{tabular}{|l|c|c|c|c|c|c|}
\hline \multicolumn{1}{|c|}{ Items } & Male & Female & $\boldsymbol{U}$-test & $p$ & $\mathbf{N}$ & $\boldsymbol{r}$ \\
\hline Your personal habits & 4.03 & 4.08 & 26536.5 & .693 & 474 & .018 \\
\hline $\begin{array}{l}\text { Things you have done in the } \\
\text { past which you feel guilty } \\
\text { about** }\end{array}$ & 3.52 & 3.12 & 21619.5 & .000 & 473 & .173 \\
\hline $\begin{array}{l}\text { Things you wouldn't do in } \\
\text { public** }\end{array}$ & 3.57 & 3.21 & 22134.0 & .001 & 473 & .156 \\
\hline Your deepest feelings & 3.49 & 3.63 & 25726.0 & .342 & 474 & .044 \\
\hline $\begin{array}{l}\text { What you like and dislike } \\
\text { about yourself }\end{array}$ & 3.35 & 3.37 & 26725.0 & .992 & 471 & .001 \\
\hline $\begin{array}{l}\text { What is important to you and } \\
\text { your life }\end{array}$ & 3.65 & 3.82 & 24958.0 & .157 & 473 & .065 \\
\hline $\begin{array}{l}\text { What's important for you to be } \\
\text { you }\end{array}$ & 3.21 & 3.03 & 24913.0 & .131 & 474 & .069 \\
\hline The things you most fear* & 3.22 & 2.91 & 23384.0 & .010 & 474 & .118 \\
\hline Things you hold pride in*** & 3.46 & 3.02 & 21021.5 & .000 & 473 & .191 \\
\hline $\begin{array}{l}\text { Your close relationships with } \\
\text { other people** }\end{array}$ & 3.65 & 3.37 & 23066.5 & .006 & 473 & .126 \\
\hline
\end{tabular}

Note: $*: p<.05,{ }^{* *}: p<.01,{ }^{* * *}: p<.001$. Source: Fankhauser 2017: 57.

On the other hand, there is no indication of gender differences in same-gender friendships when it comes to students talking about their habits, deepest feelings, things they like or dislike about themselves, or things important to them or which they consider to define themselves.

Table 6: Self-disclosure to different-gender friend by topic: Means (Measure B)

\begin{tabular}{|l|c|c|c|c|c|c|}
\hline \multirow{2}{*}{\multicolumn{1}{|c|}{ Items }} & \multicolumn{3}{|c|}{ Male } & \multicolumn{3}{c|}{ Female } \\
\cline { 2 - 7 } & $\mathrm{N}$ & Mean & SD & $\mathrm{N}$ & Mean & SD \\
\hline Your personal habits & 245 & 3.70 & 1.07 & 169 & 3.26 & 1.19 \\
\hline $\begin{array}{l}\text { Things you have done in the past } \\
\text { which you feel guilty about }\end{array}$ & 245 & 2.94 & 1.21 & 169 & 2.61 & 1.21 \\
\hline Things you wouldn't do in public & 245 & 2.80 & 1.17 & 169 & 2.49 & 1.12 \\
\hline Your deepest feelings & 245 & 3.25 & 1.27 & 169 & 2.79 & 1.29 \\
\hline $\begin{array}{l}\text { What you like and dislike about } \\
\text { yourself }\end{array}$ & 244 & 3.25 & 1.22 & 169 & 2.88 & 1.20 \\
\hline $\begin{array}{l}\text { What is important to you and } \\
\text { your life }\end{array}$ & 245 & 3.60 & 1.07 & 169 & 3.21 & 1.17 \\
\hline What's important for you to be you & 245 & 2.93 & 1.22 & 168 & 2.70 & 1.17 \\
\hline The things you most fear & 245 & 2.80 & 1.27 & 169 & 2.57 & 1.22 \\
\hline Things you hold pride in & 245 & 3.23 & 1.18 & 169 & 2.66 & 1.12 \\
\hline $\begin{array}{l}\text { Your close relationships with } \\
\text { other people }\end{array}$ & 245 & 3.34 & 1.16 & 169 & 2.85 & 1.21 \\
\hline
\end{tabular}

See Table 4. Source: Fankhauser 2017: 47. 
Table 6 shows average scores of self-disclosure to different-gender friend by topic, as assessed using measure B. Among the ten topics included, both genders reported to be sharing most about their personal habits, as well as those things that are important to them and their lives. Topics of comparatively little disclosure were "things you wouldn't do in public," as well as "the things you most fear."

Figure 4 displays gender differences, and more detailed results of the $U$-tests are reported in Table 7:

Figure 4: Self-disclosure to different-gender friend by topic: Gender differences (Measure B)

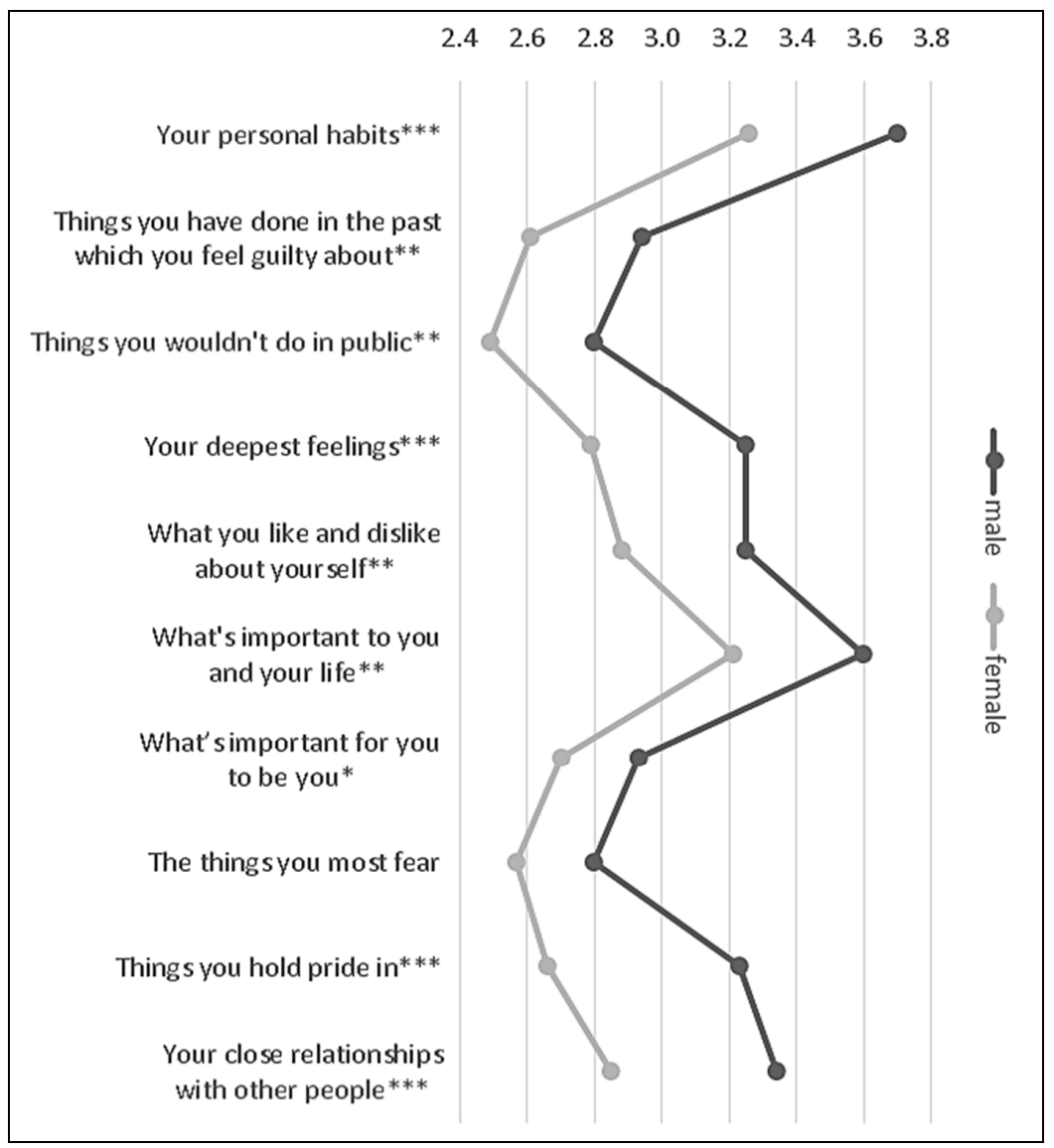

Note: ${ }^{*}: p<.05,{ }^{* *}: p<.01,{ }^{* * *}: p<.001$. Source: Fankhauser 2017: 58.

Significant gender differences are observed for all except one topic in differentgender friendships. No significant difference is found in respondents' assessment of how much they talked about things they most feared. For all of the remaining nine items, male students' self-disclosure to their close different-gender friend is significantly higher. 
Table 7: Gender differences in self-disclosure to different-gender friends: Group comparison (Measure B)

\begin{tabular}{|l|c|c|c|c|c|c|}
\hline \multicolumn{1}{|c|}{ Items } & Male & Female & $\boldsymbol{U}$-test & $p$ & $\mathbf{N}$ & $\boldsymbol{r}$ \\
\hline Your personal habits & 3.70 & 3.26 & 16299.0 & .000 & 414 & .189 \\
\hline $\begin{array}{l}\text { Things you have done in the } \\
\text { past which you feel guilty } \\
\text { about** }\end{array}$ & 2.94 & 2.61 & 17521.0 & .006 & 414 & .134 \\
\hline $\begin{array}{l}\text { Things you wouldn't do in } \\
\text { public** }\end{array}$ & 2.80 & 2.49 & 17603.0 & .007 & 414 & .132 \\
\hline Your deepest feelings & 3.25 & 2.79 & 16590.0 & .000 & 414 & .174 \\
\hline $\begin{array}{l}\text { What you like and dislike } \\
\text { about yourself }\end{array}$ & 3.25 & 2.88 & 17095.0 & .002 & 413 & .149 \\
\hline $\begin{array}{l}\text { What is important to you and } \\
\text { your life }\end{array}$ & 3.60 & 3.21 & 16733.0 & .001 & 414 & .169 \\
\hline $\begin{array}{l}\text { What's important for you to be } \\
\text { you }\end{array}$ & 2.93 & 2.70 & 18312.0 & .050 & 413 & .096 \\
\hline The things you most fear* & 2.80 & 2.57 & 18560.5 & .066 & 414 & .090 \\
\hline Things you hold pride in*** & 3.23 & 2.66 & 14998.5 & .000 & 414 & .241 \\
\hline $\begin{array}{l}\text { Your close relationships with } \\
\text { other people** }\end{array}$ & 3.34 & 2.85 & 15967.0 & .000 & 414 & .200 \\
\hline
\end{tabular}

Note: ${ }^{*}: p<.05,{ }^{* *}: p<.01,{ }^{* * *}: p<.001$. Source: Fankhauser 2017: 58.

\section{Gender Difference in the Self-Disclosure Indices}

The above tables and figures show the results for each item included in the two selfdisclosure measures separately. As already mentioned, both batteries of items on self-disclosure are used to create non-weighted additive indices. In Table 8 , means for these indices towards both same-gender and different-gender friends are reported.

Table 8: Indices of self-disclosure by disclosure target and gender of respondent

\begin{tabular}{|c|c|c|c|c|c|c|c|}
\hline \multirow{2}{*}{$\begin{array}{l}\text { Measure of } \\
\text { self- } \\
\text { disclosure }\end{array}$} & \multirow{2}{*}{ Disclosure target } & \multicolumn{3}{|c|}{ Male } & \multicolumn{3}{|c|}{ Female } \\
\hline & & $\mathrm{N}$ & Mean & SD & $\mathrm{N}$ & Mean & $\mathrm{SD}$ \\
\hline \multirow{2}{*}{ Measure A } & Same-gender friend & 282 & 3.44 & 1.02 & 192 & 3.22 & 1.11 \\
\hline & Different-gender friend & 242 & 2.96 & 1.02 & 169 & 2.49 & 1.07 \\
\hline \multirow{2}{*}{ Measure B } & Same-gender friend & 280 & 3.52 & 0.86 & 188 & 3.36 & 0.71 \\
\hline & Different-gender friend & 244 & 3.18 & 0.74 & 165 & 2.80 & 0.81 \\
\hline
\end{tabular}

Source: Fankhauser 2017: 48.

Using measure A, mean responses ranged from 2.49 to 3.44 , whereas the lowest average is reported for female students' disclosure to their close friends of a different-gender and highest is reported for male students' disclosure to friends of the same sex. Similar results are found in the case of measure B, where means range from 2.80 to 3.52 . 
In the case of the combined index of measure A, the greater disclosure of male students only approaches significance in same-gender friendships $(u=24325.5, p$ $=.060$ ). In different-gender friendships, however, this difference is highly significant $(u=15191, p<.001)$. As for measure $\mathrm{B}$, men scored significantly higher than women for both same-gender $(u=23341, p=.038)$ and different-gender friendships $(u=14758.5, p<.001)$. Yet, here too, the finding is more robust in the case of different-gender friendships.

\section{Differences in Overall Self-Disclosure by Disclosure-Target}

Self-disclosure as measured with both indices was also compared by disclosure target. Due to the non-normal distribution of the data, Wilcoxon signed-rank tests were conducted, indicating that self-disclosure was lower to different-gender than to same-gender friends when using both measure A $(z=-11.021, p<.001, r=.384)$ and measure $\mathrm{B}(z=-11.137, p<.001, r=.390)$, with medium effect sizes.

Wilcoxon tests were also conducted after separating the respondents by gender. Results for measure A are highly significant both for men $(z=-7.592, p<.001)$ and women $(z=-8.065, p<.001)$, with higher disclosure in same-gender friendships. Using measure B produces similar results for male $(z=-7.849, p<.001)$ and female students $(z=-7.977, p<.001)$. Results for both indices show greater effect sizes in the case of female students ( $r=.439$ and $r=.439$ respectively), as opposed to their male colleagues ( $r=.345$ and $r=.356$ respectively). Thus, both male and female students share more with their same-gender friends than with their different-gender ones. Additionally, there is indication that this difference is greater in the case of female students. In this regard, measures A and B yield quite similar results.

\section{Gender Difference in Other Main Variables}

Subjective closeness: In Table 9, average scores of the Subjective Closeness Index (calculated from two items) are reported. On a scale from 0 to 97, the subjective closeness felt to same-gender friend was assessed with an average of 75.03 by male students and 75.12 by female students. In different-gender friendships these means were at 60.63 and 56.68 , respectively.

Table 9: Subjective closeness by type of relationship and respondent's gender: Means

\begin{tabular}{|c|c|c|c|c|c|c|}
\hline \multirow{2}{*}{ Subjective Closeness Index } & \multicolumn{3}{|c|}{ Male } & \multicolumn{3}{c|}{ Female } \\
\cline { 2 - 7 } & $\mathrm{N}$ & Mean & SD & N & Mean & SD \\
\hline Same-gender friendship & 278 & 75.03 & 14.26 & 189 & 75.12 & 13.53 \\
\hline Different-gender friendship & 240 & 60.63 & 20.80 & 165 & 56.68 & 22.60 \\
\hline
\end{tabular}

Source: Fankhauser 2017: 51. 
No significant gender difference in subjective closeness is found in the case of samegender friendships, and only a negligible difference can be identified in the case of different-gender friendships $(u=17529.0, p=.050, r=.097)$. Both male and female students consider their most intimate same-gender friendship to be significantly closer than their most intimate different-gender friendship (male: $z=9.280, p<.001$, $r=.424$; female: $z=-8.344, p<.001, r=.462$ ).

Trust in friendship stability: Table 10 shows respondents' average trust in friendship stability by gender and type of friendship. Respondents were asked to assess the likelihood that their friendships would still be the same after ten years. On a scale from 0 to 97, where the latter expresses the highest likelihood of still being friends ten years later, male students reported an average of 76.68 in respect to their best same-gender friend and 54.14 in respect to their best different-gender friend. In the case of female students, these averages were quite similar at 76.69 and 52.83, respectively.

Table 10: Trust in friendship stability by type of relationship and respondent's gender: Means

\begin{tabular}{|c|c|c|c|c|c|c|}
\hline \multirow{2}{*}{ Trust in friendship stability } & \multicolumn{3}{|c|}{ Male } & \multicolumn{3}{c|}{ Female } \\
\cline { 2 - 7 } & $\mathrm{N}$ & Mean & SD & N & Mean & SD \\
\hline Same-gender friendship & 279 & 76.68 & 19.05 & 192 & 76.69 & 19.62 \\
\hline Different-gender friendship & 241 & 54.14 & 27.67 & 167 & 50.95 & 28.98 \\
\hline
\end{tabular}

Source: Fankhauser 2017: 52.

Group comparison revealed no significant effect of respondents' gender. However, type of friendship - that is, whether the respondent is considering a same-gender or a different-gender friendship - did make a substantial and statistically significant difference. Wilcoxon tests showed that male students $(z=-10.483, p<.001, r$ $=.477)$ as well as their female colleagues $(z=-8.766, p<.001, r=.480)$ clearly displayed higher confidence in a stable friendship when talking about same-gender friends (as opposed to different-gender friends).

79.8 per cent of male students and 75.4 per cent of female students reported that the person to whom they most readily disclosed information was their best samegender friend. 14.2 per cent of male students and 8.2 per cent of female students chose their different-gender friend instead (see Table 11). Among the 6.0 per cent of male and 16.4 per cent of female respondents who chose somebody other than the above two, most considered it to be either their mother, a sibling, or their boyfriend/girlfriend. 
Table 11: Primary disclosure targets

\begin{tabular}{|l|c|c|c|c|}
\hline \multirow{2}{*}{} & & \multicolumn{3}{|c|}{ Primary disclosure target (\%) } \\
\cline { 2 - 5 } & $\mathrm{N}$ & Same-gender friend & Different-gender friend & Somebody else \\
\hline Male & 267 & $79.8 \%(213)$ & $14.2 \%(38)$ & $6.0 \%(16)$ \\
\hline Female & 183 & $75.4 \%(138)$ & $8.2 \%(15)$ & $16.4 \%(30)$ \\
\hline Total & 450 & $78.0 \%(351)$ & $11.8 \%(52)$ & $10.2 \%(46)$ \\
\hline
\end{tabular}

Source: Fankhauser 2017: 53.

Overall, these findings support the dominant view in existing literature on students' self-disclosure, i.e., that disclosure in this stage of life is generally greatest to samegender friends as opposed to different-gender friends or family members, and that this is especially the case for men (e.g., Jourard 1971b; Enomoto 1987 and 1997).

\section{Intercorrelations}

In this section, intercorrelations of the variables presented above are reported. All procedures are non-parametric correlations according to Spearman. Similar to the above discussion, results are reported separately by type of friendship and respondent's gender.

\section{Same-Gender Friendships}

Table 12 reports correlation coefficients for same-gender friendships between selfdisclosure measure A and measure B, subjective closeness, and respondent's trust in the durability of the friendship. All associations are positive, meaning that greater subjective closeness as well as greater trust in the durability of the friendship are likely to be found in relationships with greater self-disclosure.

Table 12: Association effects in same-gender friendships

\begin{tabular}{|c|c|c|c|c|c|c|}
\hline \multirow{2}{*}{ Variable } & \multicolumn{3}{|c|}{ MALE $(\mathrm{n}=280)$} & \multicolumn{3}{c|}{ FEMALE (n=192) } \\
\cline { 2 - 7 } & $(2)$ & $(3)$ & $(4)$ & $(2)$ & $(3)$ & $(4)$ \\
\hline Measure A (1) & $.676^{* * *}$ & $.431 * * *$ & $.415^{* * *}$ & $.615^{* * *}$ & $.411^{* * *}$ & $.421 * * *$ \\
\hline Measure B (2) & -- & $.438^{* * *}$ & $.360^{* * *}$ & -- & $.347 * * *$ & $.278^{* * *}$ \\
\hline $\begin{array}{c}\text { Subjective close- } \\
\text { ness (3) }\end{array}$ & & -- & $.626^{* * *}$ & & & $.546^{* * *}$ \\
\hline $\begin{array}{c}\text { Trust in friendship } \\
\text { stability (4) }\end{array}$ & & & -- & & & -- \\
\hline
\end{tabular}

Source: Fankhauser 2017: 64. 
It is evident that the two measures of self-disclosure correlate strongly in both the male and female sample but they are not identical. Measure A is moderately associated with subjective closeness as well as trust in friendship stability for men and women. However, the association between measure B and subjective closeness is below the 'moderate' threshold of the female sample, as is the case for this measure of self-disclosure and its association to trust in friendship stability regardless of gender.

Subjective closeness and trust in friendship stability are strongly correlated for male same-gender friendships and moderately correlated in friendships between women. The results also imply that trust in friendship stability and subjective closeness are two concepts that are strongly related. Calculation of Fisher's $z$ showed that none of the gender differences in the correlation coefficients were statistically significant.

\section{Different-Gender Friendships}

Similar results are found in the case of close different-gender friendships. Table 13 shows correlation coefficients after separating by respondents' gender. Again, the different measures of self-disclosure are strongly correlated.

Table 13: Association effects in different-gender friendships

\begin{tabular}{|c|c|c|c|c|c|c|}
\hline \multirow{2}{*}{ Variable } & \multicolumn{3}{|c|}{ MALE (n=280) } & \multicolumn{3}{c|}{ FEMALE (n=192) } \\
\cline { 2 - 7 } & $(2)$ & $(3)$ & $(4)$ & $(2)$ & $(3)$ & $(4)$ \\
\hline Measure A (1) & $.603 * * *$ & $.426 * * *$ & $.343^{* * *}$ & $.701 * * *$ & $.387 * * *$ & $.416^{* * *}$ \\
\hline Measure B (2) & -- & $.553^{* * *}$ & $.450 * * *$ & -- & $.497 * * *$ & $.521 * * *$ \\
\hline $\begin{array}{c}\text { Subjective close- } \\
\text { ness (3) }\end{array}$ & & -- & $.631 * * *$ & &.- & $.687 * * *$ \\
\hline $\begin{array}{c}\text { Trust in friendship } \\
\text { stability (4) }\end{array}$ & & & -- & & & - \\
\hline
\end{tabular}

Source: Fankhauser 2017: 66.

Subjective closeness is moderately associated with measure A in the case of men and weakly in the case of women. As for measure B, this association is moderate for both gender groups. Trust in friendship stability is weakly associated with measure $\mathrm{A}$ in the case of men, whereas a moderate association can be found for female students. Using measure B, the correlation is moderate for both genders.

The close connection between subjective closeness and trust in friendship stability is replicated in the case of different-gender friendships- - here the association is strong among female respondents as well. As tests for Fischer's $z$ reveal, none of the differences between the coefficients for male and female students are significant. 
It was also tested whether association effects differed significantly from each other by disclosure target, that is, type of friendship. In this regard only one finding can be reported: in the case of female friendships, the association between trust in friendship stability and subjective closeness was significantly stronger in differentgender than same-gender friendships $(z=-2.14, p=.032)$.

\section{Discussion}

Most studies regarding self-disclosure and gender differences in Japan conclude (or, indeed, depart from the assumption) that women's disclosure is greater than men's (Enomoto 1987 and 1997; Shimakura and Miyamoto 2013). There are some exceptions indicating that women's disclosure is only greater in same-gender friendships - or which find hardly any gender differences at all. One study found that women's disclosure was lower than men's in different-gender friendships (Takeuchi 2010). However, I am not aware of any research as clearly indicating higher selfdisclosure by men as the present study in both close same-gender and close different-gender friendships.

Male students reported significantly higher self-disclosure in different-gender friendships, regardless of measure of self-disclosure. Yet, even in close same-gender friendships, men's self-disclosure as measured by the Self-Disclosure Index (measure B) was significantly greater in this study. When using self-disclosure measure A, this gender effect only approached significance; but, here too, whenever individual items yielded significant differences, it was always men's disclosure which was higher. This effect was not limited to subjects stereotypically defined as 'masculine' or even 'neutral' (for terminology, cf. Derlega et al. 1981). Female students were less likely than male students to share information about their secrets, embarrassing experiences, and failures in same-gender friendships. In the case of different-gender friendships, women's self-disclosure was lower also for the remaining two topics of this measure: the students' greatest worries and worst experiences.

The analysis of the ten items of measure B produced similar results. In the case of same-sex friendships, no gender differences were found for five out of ten topics, including "Your deepest feelings" and "What you like and dislike about yourself." For those five topics where gender differences were found, including "Things you hold pride in" and "Your close relationships with other people," men's disclosure was always higher. This alone indicates a lack of support for the traditional finding that women's disclosure is greater in same-gender friendships and especially when talking about emotions (e.g., Enomoto 1987). In different-gender friendships, men's disclosure was greater in nine out of ten topics, now also including "Your deepest feelings." Thus, even when considering a subject typically given the label 'femi- 
nine,' men reported significantly higher disclosure. Overall, effect sizes of gender tended to be non-significantly greater in the case of different-gender friendships.

The other two aspects included in this analysis - trust in friendship stability and subjective closeness felt towards the friend-yielded no overall gender differences. Men and women alike felt significantly closer to their same-gender friend and considered this relationship more likely to remain unchanged over time than with regard to their different-gender friend(s). Regarding the degree of closeness felt within the friendship, no significant differences were found irrespective of type of friendship, thus confirming early results (e.g., Caldwell and Peplau 1982).

Correlation analysis showed that these two variables were weakly to moderately associated with the two measures of self-disclosure, supporting both the reciprocity of disclosure and intimacy, as well as the notion that a safe sharing environment (i.e., a stable friendship) is positive for disclosure. The slight differences in effect size between the genders were not consistent across the two measures of self-disclosure. This can be taken as an indication that neither subjective closeness nor trust in relationship stability offer a good explanation for gender differences in selfdisclosure. Nevertheless, the two variables are strongly correlated in three out of four subgroups by gender of respondent and type of relationship. From this, one can infer that intimacy and the faith in a lasting friendship are very much intertwined. As for the connection between the two measures of disclosure themselves, correlation analysis revealed that they were strongly associated but still, to a certain degree, seemed to measure different aspects of self-disclosure.

The overall differences in self-disclosure summed up above suggest that a greater barrier inhibiting self-disclosure exists for female students as opposed to their male colleagues - and this barrier seems to be felt by female students particularly in friendships with different-gender persons. Differently put, men seem to be less restricted in their disclosure-behaviour than women in this regard, much opposed to the common explanations in self-disclosure research. The present study may be an example reflecting changes taking place in the way young Japanese men and women communicate and interact with each other in friendships. It could be taken as a potential indication of a dissolution of traditional gendered behavioural patterns in this particular relationship constellation.

At the very least, the traditional gender roles which served as an explanation for women's greater self-disclosure in the works of Jourard (1971b) and Enomoto $(1987 ; 1997)$ cannot explain the results found in this study. In their view, men are socialised in a way that would make them more prone to abstain from intimate disclosure in comparison to women. The normative image of manhood-defining men as silent and unemotional - and the presupposition that women are talkative and eager to share their emotions and information about themselves, which are discussed in these works, are not at all supported by the data in the present study. 
This might have to do with the fact that images and lived experiences of masculinity and femininity have become more diverse in present day Japan (McLelland and Dasgupta 2005; Iida 2005; Darling-Wolf 2004). There is also research indicating a diminishing of differences between gender roles and characteristics traditionally regarded as masculine and feminine (Sugihara and Katsurada 2002). Drawing from the argument by Derlega et al. (1993: 43-50), who actually used it to explain the greater self-disclosure of women, socialisation processes within gendered subcultures certainly play a role for disclosure behaviour. A subculture has its own norms and sanctions; and additionally, men and women might have different goals which motivate them to display varying degrees of self-disclosure (ibid.: 45).

As Sugihara and Katsurada (1999: 637) state, "the findings in gender role studies conducted 10 or 15 years ago may not be relevant or applicable to the present day." Young Japanese men today may be socialised in a fashion in which their disclosure is less sanctioned or more encouraged in same-gender and different-gender friendships than it was the case at the time of Enomoto's research. The slow dissolution of traditional gender stereotypes may have begun to 'liberate' young male students from having to appear "objective, striving, unsentimental, and emotionally unexpressive" (Jourard 1971a: 35) in social interactions. The results would also imply, however, that inhibiting factors of female self-disclosure are more present or have stayed more present in comparison to those of men. Hence, women's subcultures in Japan might not have undergone the same change in this regard. For example, there is research indicating that mainstream media might have a stronger effect on the maintenance of traditional gender roles for women than they do for men (Saito 2007). As Japan is still often labelled a "masculine cultural hegemony" (ibid.: 527), it is quite possible that men find themselves in a position where changing the rules which govern their modes of interaction poses fewer obstacles. Thus, interaction patterns (those treated here as well as others) might be more stable in the case of female students due to both internal and external reasons, and are also more likely to manifest themselves in different-gender relationships.

One possible explanation for the lower self-disclosure of women to be more pronounced in different-sex friendships is the idea that men and women have different reasons for avoiding self-disclosure. Rosenfeld et al. (1979: 72-73) have argued that disclosure-avoidance in men serves the purpose of maintaining control over a relationship, whereas women choose to avoid self-disclosure in order to limit the chance of getting hurt and having personal problems which could arise in the relationship as a consequence of having disclosed. In a study comparing the self-disclosure of American and Japanese students, Kito (2005: 130) expands this argument by theorising that "women might perceive that there would be more personal hurt and problems if they were to self-disclose to men than if they were to self-disclosure to women." In their meta-analysis of gender differences in self-disclosure Dindia and Allen (1992: 114) made the same assumption over a decade earlier. Yet neither study offers any reason 
why this might be the case. The idea is backed up, however, by the finding that the gender of the disclosure target makes a greater difference for the disclosure of women in close (but also less intimate) friendships (Dolgin et al. 1991: 325).

Interestingly enough, the finding by Dolgin et al. (1991) is supported in the present thesis. Disclosure to same-gender and to different-gender friends differed significantly for both men and women, regardless of self-disclosure measure. And although the effect sizes do not seem to differ significantly between the genders, the greater disclosure of men was consistently found to be more pronounced in different-sex friendships, where more topics revealed such an effect. However, whether this is due to the proposed explanation by Kito (2005) cannot be ascertained based on the present data.

Returning to the consideration of social surroundings, it is possible that women are still socialised in a way that makes them cautious to disclose themselves to their male friends - in line with Kito's reasoning (2005). As Moroi et al. (2010) have shown in a Japanese context, when individuals feel that intimacy is connected to a certain kind of risk, this has a detrimental effect on disclosure. This corresponds to the finding in this study that trust in friendship-stability and subjective closeness are more strongly associated with each other in female students' different-gender friendships (as opposed to same-gender ones). It implies that for female students a feeling of closeness towards a male friend is more readily established when there is greater trust in a lasting friendship, that is, when they believe that there was a smaller chance of personal hurt that might prove fatal to the relationship.

It is also telling that the portion of male students who named their female friend as primary disclosure-target was twice as big as vice versa. This too might well have to do with a dissimilar firmness of social norms that apply to young men and women in contemporary Japanese society and the way they are expected to interact.

Despite all these arguments, one limitation must be addressed in regard to the findings presented here. Although the sample in this study is considerably larger than in most studies on self-disclosure both in a Japanese and an international context, the analysis is still based on a convenience sample and all respondents were recruited in one university campus. Other environments might foster different modes of interaction, and it is possible that the greater self-disclosure of male students is limited to this environment only. Nevertheless, this study at the very least indicates that patterns of self-disclosure and interpersonal communication in friendships can stray from traditionally gendered lines. In direct comparison to earlier research, these results hint at the possibility of changing gender roles in contemporary Japan. The parameters and norms assumed to influence communication styles of young men and women might be becoming less significant or changing altogether, although this process may not be identical or taking place at the same rate for all genders. The present study shows that it is still relevant to ask for manifestations and patterns of self-disclosure because the conditions influencing disclosure are constantly changing. 


\section{REFERENCES}

Altman, Irwin and Dalmas A. Taylor. 1973. Social Penetration: The Development of Interpersonal Relationships. New York: Holt, Rinehart and Winston.

Andō, Kiyoshi 安藤清志. 1986. “Taijin kankei ni okeru jiko kaiji no kinō 対人関係における自 己開示の機能 [(Functions of) Self-disclosure in Interpersonal Relationships].” Tōkyō Joshi Daigaku Kiyō Ronshū 東京女子大学紀要論集 [Tōkyō Woman's Christian University Bulletin], 36 (2), pp. 167-199.

Andō, Kiyoshi 安藤清志. 1990. ““Jiko no sugata no hyōshutsu’ no dankai 「自己の姿の表出」 の段階 [The Step of 'Disclosure of Self'].” In Nakamura Hiyoshi 中村陽吉, ed., “Jiko katei” no shakaishinrigaku「自己過程」の社会心理学 [Psychology of “The Process of Self”]. Tōkyō: Tōkyō Daigaku Shuppan-kai, pp. 148-198.

Argyle, Michael and Monika Henderson. 1985. "The Rules of Social Relationships". In Steve Duck and Daniel Perlman, eds., Understanding Personal Relationships: An Interdisciplinary Approach. Thousand Oaks, CA: Sage, pp. 63-84.

Barnlund, Dean C. 1975. The Public Self and the Private Self in Japan and the United States. Tōkyō: The Simul Press.

Barnlund, Dean C. 1989. Communicative Styles of Japanese and Americans: Images and Realities. Belmont, CA: Wadsworth.

Bauminger, Nirit, Ricky Finzi-Dottan, Sagit Chason, and Dov Har-Even. 2008. "Intimacy in Adolescent Friendship: The Roles of Attachment, Coherence, and Self-disclosure." Journal of Social and Personal Relationships, 25 (3), pp. 409-428.

Berscheid, Ellen, Mark Snyder, and Allen M. Omoto. 1989. "The Relationship Closeness Inventory." Journal of Personality and Social Psychology, 57 (5), pp. 792-807.

Brunell, Amy B. 2007. "Self-disclosure." In Roy F. Baumeister and Kathleen D. Vohs, eds., Encyclopedia of Social Psychology. Los Angeles: Sage, pp. 810-811.

Caldwell, Mayta A. and Letitia Anne Peplau. 1982. "Sex Differences in Same-sex Friendship." Sex Roles, 8 (7), pp. 721-732.

Chen, Guo-Ming. 1995. "Differences in Self-disclosure Patterns among Americans versus Chinese: A Comparative Study." Journal of Cross-Cultural Psychology, 26 (1), pp. 84-91.

Cohen, Jacob. 1988. Statistical Power Analysis for the Behavioral Sciences. New York: Routledge.

Collins, Nancy L. and Lynn Carol Miller. 1994. "Self-disclosure and Liking: A Meta-analytic Review." Psychological Bulletin, 116 (3), pp. 457-475.

Darling-Wolf, Fabienne. 2004. "Women and New Men: Negotiating Masculinity in the Japanese Media." The Communication Review, 7 (3), pp. 285-303.

Daubman, Kimberly A. and Harold Sigall. 1997. "Gender Differences in Perceptions of How Others are Affected by Self-disclosure of Achievement.” Sex Roles, 37 (1-2), pp. 73-89.

Derlega, Valerian J., Bonnie Durham, Barbara Gockel, and David Sholis. 1981. "Sex Differences in Self-disclosure: Effects of Topic Content, Friendship, and Partner's Sex.” Sex Roles, 7 (4), pp. 433-447.

Derlega, Valerian J., Sandra Metts, Sandra Petronio, and Stephen T. Margulis. 1993. SelfDisclosure. Newbury Park, CA: Sage.

Dindia, Kathryn and Mike Allen. 1992. "Sex Differences in Self-disclosure: A Meta-analysis." Psychological Bulletin, 112 (1), pp. 106-124.

Dolgin, Kim Gale and Nozomi Minowa. 1997. "Gender Differences in Self-presentation: A Comparison of the Roles of Flatteringness and Intimacy in Self-disclosure to Friends." Sex Roles, 36 (5), pp. 371-380. 
Dolgin, Kim Gale, Leslie Meyer, and Janet Schwartz. 1991. "Effects of Gender, Target's Gender, Topic, and Self-Esteem on Disclosure to Best and Midling Friends." Sex Roles, 25 (5-6), pp. 311-329.

Enomoto, Hiroaki 榎本博明. 1987. “Seinenki (daigakusei) ni okeru jiko kaijisei to sono seisa ni tsuite 青年期（大学生）における自己開示性とその性差について [Self-disclosure Patterns of College Students and Gender-differences Therein].” Shinrigaku Kenkyū 心理学研究 [Japanese Journal of Psychology], 58, pp. 91-97.

Enomoto, Hiroaki 榎本博明. 1997. Jiko kaiji no shinrigakuteki kenkyū 自己開示の心理学的研究 [The Psychological Study of Self-disclosure]. Kyōtō: Kitaōji-Shobō.

Evans, James D. 1996. Straightforward Statistics for the Behavioral Sciences. Pacific Grove: Brooks/Cole.

Fankhauser, Peter. 2017. "Sharing is Caring: Self-disclosure in Friendships of Japanese Students and the Role of Relational Mobility." M.A. thesis, University of Vienna, Austria.

Fisher, Nicole and Choi Seong In. 2013. "What are College Students Afraid of Disclosing and to Whom? An Adaptation and Extension of the Self-disclosure Index." Journal of Asia Pacific Counseling, 3 (2), pp. 113-130.

Horesh-Reinman, Netta. 2011. "Self Disclosure and Self Criticism in Adolescents." European Psychiatry, 26, pp. 1022-1022.

Iida, Yumiko. 2005. "Beyond the 'Feminization of Masculinity': Transforming Patriarchy with the 'Feminine' in Contemporary Japanese Youth Culture.” Inter-Asia Cultural Studies, 6 (1), pp. $56-74$.

Jourard, Sidney M. 1958. “A Study of Self-disclosure.” Scientific American, 198, pp. 77-82.

Jourard, Sidney M. 1971a [1 1964]. The Transparent Self. New York: D. van Nostrand.

Jourard, Sidney M. 1971b. Self-Disclosure: An Experimental Analysis of the Transparent Self. New York: Wiley-Interscience.

Jourard, Sidney M. and Paul Lasakow. 1958. "Some Factors in Self-disclosure.” Journal of Abnormal Psychology, 56 (1), pp. 91-98.

Jourard, Sidney M. and Patricia Richman. 1963. "Disclosure Output and Input in College Students." Merrill Palmer Quarterly, 9, pp. 141-148.

Kito, Mie. 2005. "Self-disclosure in Romantic Relationships and Friendships among American and Japanese College Students.” The Journal of Social Psychology, 145 (2), pp. 127-140.

La Gaipa, John J. 1977. "Testing a Multidimensional Approach to Friendship.” In Steve Duck, ed., Theory and Practice in Interpersonal Attraction. London: Academic Press, pp. 249-270.

Ledbetter, Andrew M., Joseph P. Mazer, Jocelyn M. Degroot, Kevin R. Mayer, Yuping Mao, and Brian Swafford. 2011. "Attitudes toward Online Social Connection and Self-disclosure as Predictors of Facebook Communication and Relational Closeness." Communication Research, 38 (1), pp. 27-53.

Maeda, Eriko and L. David Ritchie. 2003. "The Concept of shinyuu in Japan: A Replication of and Comparison to Cole and Bradac's Study on U.S. Friendship." Journal of Social and Personal Relationships, 20 (5), pp. 579-598.

McLelland, Mark and Romit Dasgupta, eds. 2005. Genders, Transgenders and Sexualities in Japan. London: Routledge.

Miller, Lynn C., John H. Berg, and Richard L. Archer. 1983. "Openers: Individuals who Elicit Intimate Self-disclosure.” Journal of Personality and Social Psychology, 44 (6), pp. 12341244.

Moroi, Katsuhide 諸井克英, Iwasa Naomi 岩佐直美, and Ueki Yoshie 植木美枝. 2010. “Dōsei shinyū ni tai suru jiko kaiji ni oyobosu kōsai kikan no nagasa no eikyō 同性親友に対する自己 開示におよぼす交際期間の長さの影響 [Effects of the Length of Friendship on Self- 
disclosure with the Same-sex Close Friend]." Dōshisha Joshi Daigakusei Seikatsu Kagaku 同志 社女子大学生生活科学 [Dōshisha Women's College of Liberal Arts Life Sciences], 44, pp. 22-29. Niwa, Sora 丹羽空 and Maruno Shun'ichi 丸野俊一. 2010. “Jiko kaiji no fukusa o sokutei suru shakudo no kaihatsu 自己開示の深さを測定する尺度の開発 [Development of a Scale to Assess the Depth of Self-disclosure]." Pāsonariti Kenkyū パーソナリティ研究 [Personality Research], 18 (3), pp. 196-209.

Noguchi, Emi 野口恵美. 2011. "Daigakusei no jiko kaiji manzokukan to intānetto jō no jiko kaiji tokuchō oyobi kodokukan to no kanren 大学生の自己開示満足感とインターネット上の自 己開示特徵および孤独感との関連 [University Students' Self-disclosure Satisfaction, Selfdisclosure Function on the Internet, and Relation to Loneliness]." Kyūshü Daigaku Shinrigaku Kenkyū 九州大学心理学研究 [Kyūshū University Psychological Research], 12, pp. 121-128.

Ochiai, Yoshiyuki 落合良行 and Satō Yūkō 佐藤有耕. 1996. “Seinenki ni okeru tomodachi to no tsukiaikata no hattatsuteki henka 青年期 における友達とのつきあい方の発達的変化 [The Developmental Change of Friendship in Adolescence]." Kyōiku Shinrigaku Kenkyū 教育心理 学研究 [Japanese Journal of Educational Psychology], 44 (1), pp. 55-65.

Omarzu, Julia and John. H. Harvey. 2012. "Interpersonal Perception and Communication.” In Vilayanur S. Ramachandran, ed., Encyclopedia of Human Behavior. Second edition. San Diego: Academic Press, pp. 465-471.

Rains, Stephen A. and Steven R. Brunner. 2018. "The Outcomes of Broadcasting Self-disclosure Using New Communication Technologies: Responses to Disclosure Vary across One's Social Network." Communication Research, 45 (5), pp. 659-687.

Rains, Stephen A., Steven R. Brunner, and Kyle Oman. 2014. "Self-disclosure and New Communication Technologies: The Implications of Receiving Superficial Self-disclosures from Friends." Journal of Social and Personal Relationships, 33 (1), pp. 42-61.

Rosenfeld, Lawrence B., Jean M. Civikly, and Jane R. Herron. 1979. "Anatomical and Psychological Sex Differences.” In Gordon J. Chelune, ed., Self-Disclosure: Origins, Patterns, and Implications of Openness in Interpersonal Relationships. San Francisco: Jossey-Bass, pp. 80-109.

Saito, Shin 'ichi. 2007. "Television and the Cultivation of Gender-role Attitudes in Japan: Does Television Contribute to the Maintenance of the Status Quo?" Journal of Communication, 57, pp. 511-531.

Schug, Joanna, Masaki Yuki, and William Maddux. 2010. "Relational Mobility Explains Betweenand Within-culture Differences in Self-disclosure to Close Friends." Psychological Science, 21 (10), pp. 1471-1478.

Shaffer, David R., Linda J. Pegalis, and Doris G. Bazzini. 1996. "When Boy Meets Girl (Revisited): Gender, Gender Role Orientation, and Prospect of Future Interaction as Determinants of Self-disclosure among Same- and Opposite-sex Acquaintances." Personality and Social Psychology Bulletin, 22 (5), pp. 495-506.

Shimakura, Yui 嶋倉唯 and Miyamoto Masakazu 宮本正一. 2013. “Jiko kaiji to kodokukan no kanren 自己開示と孤独感との関連 [The Relationship of Self-disclosure and Loneliness].” Gifu Daigaku Kyōikugakubu Kenkyū Hōhō: Jinbunkagaku 岐阜大学教育学部研究報告: 人 文科学 [Gifu University Bulletin: Humanities], 62 (1), pp. 143-152.

Sprecher, Susan and Susan Hendrick. 2004. "Self-disclosure in Intimate Relationships: Associations with Individual and Relationship Characteristics Over Time." Journal of Social and Clinical Psychology, 23 (6), pp. 857-877.

Sugihara, Yoko and Katsurada Emiko. 1999. "Masculinity and Femininity in Japanese Culture: A Pilot Study." Sex Roles, 40 (7), pp. 635-646.

Sugihara, Yoko and Katsurada Emiko. 2002. "Gender Role Development in Japanese Culture: Diminishing Gender Role Differences in a Contemporary Society.” Sex Roles, 47 (9), pp. 443-452. 
Takeda, Yūko 武田裕子, Maeda Ken'ichi 前田健一, Tokuoka Masaru 德岡大, and Ishida Yumi 石田弓. 2012. “Daigakusei no shinmitsudo no kotonaru yūjin e no jiko kaiji to shinwa dōki no kankei 大学生の親密度の異なる友人への自己開示と親和動機の関係 [The Relation between Self-disclosure to Friends of Three Different Levels of Intimacy and Affiliation Motive in University Students]." Hiroshima Daigaku Daigakuin Shinri rinshō Kyōiku Kenkyū Sentā Kiyō 広島大学大学院心理臨床教育研究センター紀要 [Bulletin of the Training and Research Centre for Clinical Psychology at Hiroshima University], 11, pp. 97-108.

Takeuchi, Yumi 竹内由美. 2010. "Daigakusei no yūjin kankei ni okeru jiko kaiji to kodokukan no kankei 大学生の友人関係における自己開示と孤独感の関係 [Self-disclosure and Loneliness in College Student Friendships].” Shinri Sōdan Sentā Nenpō 心理相談センター年報 [Annual report of the Psychological Counselling Centre], 6, pp. 15-22.

Tang, Jih-Hsin and Wang Cheng-Chung. 2012. "Self-Disclosure among Bloggers: Re-examination of Social Penetration Theory." Cyberpsychology Behavior and Social Networking, 15 (5), pp. 245-250.

Taylor, Dalmas and Irwin Altman. 1987. "Communication in Interpersonal Relationships: Social Penetration Processes." In Michael E. Roloff and Gerald R. Miller, eds., Interpersonal Processes: New Directions in Communication Research. Newbury Park, CA: Sage, pp. 257-277.

Taylor, Dalmas A. and Melissa Hinds. 1985. "Disclosure Reciprocity and Liking as a Function of Gender and Personalism." Sex Roles, 12 (11), pp. 1137-1153.

Thase, Michael and Richard A. Page. 1977. "Modeling of Self-disclosure in Laboratory and Nonlaboratory Interview Settings.” Journal of Counseling Psychology, 24 (1), pp. 35-40.

Ting-Toomey, Stella. 1991. "Intimacy Expressions in Three Cultures: France, Japan, and the United States.” International Journal of Intercultural Relations, 15 (1), pp. 29-46.

Ue, Hiroshi 宇惠弘 and Horiuchi Hiroe 堀内弘惠. 2012. “Dejitaru neitibu sedai no jiko kaiji ni kan suru ikkōsatsu デジタル・ネイティブ世代の自己開示に関する一考察 [On the Selfdisclosure of the Digital Native Generation]." Annual Convention of the Japanese Association of Educational Psychology, 54, p. 488.

Wada, Minoru 和田実. 1993. “Dōsei yūjin kankei: Sono sei oyobi seiyakuwari taipu ni yoru sai 同 性友人関係: その性および性役割タイプによる差異 [Same-sex Friendships: Effects of Sex and Sex-role Type]." Japanese Journal of Social Psychology (Before 1996, Research in Social Psychology), 8 (2), pp. 67-75.

Walker, Lily S. and Paul H. Wright. 1976. "Self-disclosure in Friendship." Perceptual and Motor Skills, 42 (3), pp. 735-742.

\section{ABBREVIATIONS}

ESDQ

JSDQ

US

\section{GLOSSARY}

Enomoto Hiroaki

jiko kaiji

Tōkyō-to
Enomoto Self-Disclosure Questionnaire

Jourard Self-Disclosure Questionnaire

United States
榎本 博明

自己開示

東京都 most prominent researcher on self-disclosure in Japan self-disclosure, the sharing of information about the self Tōkyō prefecture 